\title{
Educational Technology Implementation in Private Universities in Erbil City
}

\author{
Mohammad Salim Abdulrahman ${ }^{1}$ \\ ${ }^{1}$ IT Department, Tishk International University, Erbil, Iraq \\ Correspondence: Mohammad Salim Abdulrahman, Tishk International University, Erbil, Iraq. \\ Email: mohammad.salim@ishik.edu.iq
}

Received: December 19, 2018 Accepted: February 17, $2019 \quad$ Online Published: March 1, 2019

doi: 10.23918/ijsses.v5i3p303

\begin{abstract}
These days technologies have become in many parts of life more than ever before. One of the major challenges in dealing with various technologies is to implement them in a useful way to improve life quality. Since educational technologies can play a big role in developing both the teaching and learning process, that's why the author chose this field for this research. The purpose of this paper is to explore the status of educational technology in a few selected private universities inside Erbil city to get a perception of development areas and to develop a survey for that purpose. To fulfil the objective of this paper, the author presented these study findings based on the developed survey, observations, interviews, and related work to develop an educational technology investment in universities. The result shows that the majority of private universities still have no Learning Management System (LMS) to manage classroom activities. In addition, many instructors are using some LMSs to incorporate technology in classrooms. The result of this paper also shows that classroom technology should be developed and extended beyond using projectors and emails.
\end{abstract}

Keyword: Educational Technology, Private Universities, Edmodo, Moodle, Google Classroom

\section{Introduction}

As a matter of fact, to make a country developed in most fields like socially, economically, politically, and technologically there should be a focus on offering quality education of that country which will be reflected. Technology has changed the way of education and learning. For the Kurdistan region government, it is important to invest in the education sector to face different kinds of problems, because if there is an active education process it could guide the whole community to prosperity. For improving education, it is imperative to take advantage of modern technology which becomes a crucial factor in providing traditional and online education. The field which concerns with exploiting technology in education called educational technology.

In this paper, the focus is going to be on what educational technology is, and how it could serve education in Kurdistan region. Association for Educational Communications and Technology (AECT) defined educational technology as "the study and ethical practice of facilitating learning and improving performance by creating, using, and managing appropriate technological process and resources" (Mishra, 2009). There is another definition which is more technical: educational technology is a general term which has been utilized to reference computer-assisted instruction (CAI), simulations, games, or lab instruments, or technology software/hardware (Delgado, Wardlow, O’Malley \& McKnight, 2015). 
The author derived a definition of educational technology which is the process of integrating technology in education to facilitate the way of learning by a set of technological tools that increases the level of interactivity during the learning sessions. However, the aim of educational technology is increasing efficiency, the effectiveness of the learning process and at the same time bringing pedagogical improvements for better education (Rehan \& Un, 2016).

There are many researchers who presented many types of researches related to technology implementations in learning and their works addressed in Section 2. This study aims to achieve the following goals: (a) Build a survey for checking the level of adopting educational technologies; (b) Examine the state of adopting technology in private universities in Kurdistan region of Iraq for the 2018-2019 academic year. To achieve this aim, in-depth research is undertaken to investigate the possibility of utilizing these modern technologies.

In addition, the data of this study were collected from 4 private universities in Erbil; namely, Tishk International, Cihan, Lebanese French and Bayan Universities. However, 10 samples were considered from each university. Within this context, this research is considered significant because it aims to improve using technological applications in universities. The paper is organized as follows: section two will present the related works to this paper. Afterward, section three will provide the used survey tool. In section 4, the methodology will be covered. In section 5, the finding will be discussed. Finally, the paper is concluded in section 6 and further possible research directions are presented along.

\section{Related Work}

Before looking at features of educational technology in Kurdistan, we should introduce relevant studies to explore the importance of educational technology in higher education. The implementations of educational technologies by lecturers in the teaching process in higher education has been the emphasis of numerous research studies, position papers, standards documents, and guidelines (Courts \&Tucker, 2012). Those studies discussed the relative usefulness of educational quality, online learning, student's needs, instructional support, instructional design strategies, costs and demanded teacher skills.

Anderson, Groulx and Maninger (2011) investigated relationships among students' technology-related skills and intention. In their study there were 217 participants preserved educators who responded to postcourse surveys. Results of this study showed that there is a big relation between preservice teachers' beliefs and their expected integration of technology in their future classes. The skills that were measured by this study concern with word Processors, spreadsheets, databases, presentation programs, graphical organizers, instructional software, teacher-developed web pages, and internet search engines. According to Rambe and Bere (2013), mobile learning applications can promote students' learning easily and also collaboratively, anytime and anywhere.

Another recent study by Boyinbode, Agbonifo and Ogundare (2017) has suggested that developers of a mobile learning environment could adopt WhatsApp as a suitable information delivery platform to support corresponding learning activities in a mobile learning environment. This study was conducted with a group of computer science students in the department of the Federal University of Technology, Akure, Nigeria. 
The study assessed media richness in respect with content timeliness, content richness, content accuracy and content adaptability in WhatsApp, Email, SMS, Twitter, and BBM.

When we came to the educational technology integration in modern classrooms, there are many barriers that could face efforts of integrating educational technologies. For example, some identified possible barriers of educational technology integration in many developing countries which are: insufficient financial support and infrastructure, human resource, administration support, as well as behavioral and environmental aspects (Dotong et al., 2016).

Now let us explore the situation of adopting technology in many universities within the Kurdistan region of Iraq. In the Kurdistan Region of Iraq, there are currently around (19) public and private higher education institutions (Ministry of Higher Education and Scientific Research, 2017). Fadhil and Al-Ameen (2016) tried to determine the situation of the real level of e-learning application among several private universities in the Kurdistan region of Iraq. They found that the use of tablet computers and smart boards in the elearning process is still limited.

Furthermore, the e-learning process and applications should be developed in a better way with classroom and extracurricular activities. Another research by Al-Hakeem and Abdulrahman (2017) shows a unique experience among Kurdistan universities by the implementation of e-Exam for quizzes, mid-term and final exams in one of Kurdistan private universities. This e-Exam system brought a lot of benefits and challenges to both lecturers and students who were familiar with traditional exam systems.

A recent study by Sadik (2018) found that many academicians working in private universities within Kurdistan region think that there should be more investment in technology to improve quality assurance systems and to involve today's technology. Another recent study by Ahmad, Rashid, Abdullah and Abdulla (2018) was conducted in University of Sulaimani and they found that the university provided poor electronic devices for teaching process and limited internet access, in addition, students' usage of IT skills is limited in social media communication and some information transferring purposes. Finally, adopting educational technologies require a thorough understanding of the requirements and restrictions related to brining technologies or merging them classrooms.

\section{Survey Tool}

For any comparative study, it's important to use a suitable data collection method. Otherwise, no meaningful outcomes could be expected of any study. Therefore, the data collection method of this study is based on a questionnaire administrated by the researcher at 4 private universities in Erbil (Tishk International, Cihan, Lebanese French and Bayan Universities). It is imperative to adopt a proper tool of information gathering for the following aspects: (a) the use of e-learning or LMS in universities. (b) The use of other educational technologies in education. Information about all mentioned aspects was gathered from academicians working on the selected universities, and from the practical experience of the researcher. The tool applied through the following questionnaire questions shown in Table 1 below. 
Table 1: Questionnaire questions

\begin{tabular}{|c|c|c|c|}
\hline \multicolumn{4}{|c|}{ The use of educational technology in learning } \\
\hline \multicolumn{2}{|r|}{ A- The use of e-learning in education } & Yes & No \\
\hline 1 & $\begin{array}{l}\text { Is there any Learning Management System such as } \\
\text { (Edmodo, Moodle, Google classroom, etc.) used in } \\
\text { your institution? }\end{array}$ & & \\
\hline 2 & $\begin{array}{l}\text { Are there any e-exam systems used in your institution } \\
\text { in conducting exams or quizzes? }\end{array}$ & & \\
\hline 3 & $\begin{array}{l}\text { Do you employ e-learning in extracurricular } \\
\text { activities? }\end{array}$ & & \\
\hline 4 & $\begin{array}{l}\text { Do you have an electronic application that you } \\
\text { employ to calculate your coursework grades? }\end{array}$ & & \\
\hline 5 & $\begin{array}{l}\text { Is there an e-learning embedded in your classroom } \\
\text { activities effectively? }\end{array}$ & & \\
\hline \multicolumn{2}{|r|}{$\begin{array}{l}\text { B- The use of other educational technologies in } \\
\text { education }\end{array}$} & & \\
\hline 1 & Is the smart board being used at your university? & & \\
\hline 2 & $\begin{array}{l}\text { Is your smart phones or tablets being used in the } \\
\text { learning process? }\end{array}$ & & \\
\hline 3 & $\begin{array}{l}\text { Are new technologies such as Virtual Reality, } \\
\text { Augmented reality, or Simulation are embedded in } \\
\text { learning process? }\end{array}$ & & \\
\hline 4 & $\begin{array}{l}\text { Are your lab instruments well equipped and up to } \\
\text { date? }\end{array}$ & & \\
\hline 5 & $\begin{array}{l}\text { Are these labs well utilized in using technology to } \\
\text { impart education? }\end{array}$ & & \\
\hline
\end{tabular}

\section{Methodology}

This section presents the study methodology, furthermore, a quantitative methodology is used in this study because its adequacy is accepted by many researchers (Phillips, 2006). In addition, it can deliver more expressive information which contributes to achieving the goal of this study (Al-rahmi, Othman \& Mi Yusuf, 2015). It is known that several well-known comparative methods are available; they are 
investigated to decide the one that is appropriate to this study. It is found out that Bereday's (1967) method is the most suitable since it is assumed to be as one of the finest systematized method in the field of comparative education (Kidd, 1975). This comparative method includes four different stages:

1. Data Collection and Description: at this step, useful data designated for this study is collected and demonstrated in a descriptive way to facilitate additional analysis on next stages.

2. Interpretation: the analysis of the collected information using techniques from various social sciences is involved in this stage. Moreover, many associated factors can be utilized to clarify the questions that influence the educational system.

3. Juxtaposition: Initial comparisons among many aspects such as concepts, findings, facts and principles are made to process and organize data.

4. Comparison: this is the last stage which includes final data fusion for assessment and setting the strategies for action.

5. It is important to mention that the current research society includes various academicians of the private universities in Erbil city, for the academic year 2018-2019. Additionally, the researcher applied the tool on 40 academicians; 10 from each university. After that, the answers were collected and then processed to obtain the result. Finally, the analysis of the collected data was carried out manually.

\section{Findings and Discussion}

The significant findings and their discussions are stated in this section. With respect to the first aspect which contains questions about the use of e-learning in the education process, the results are shown as percentage respective totals in Fig. 2. Regarding the use of LMS, the ratios were somewhat low in all universities except Tishk University because such systems are not popular among staff and students. It is important to mention that many departments in Tishk International University are using Edmodo as their Learning Management System (LMS) to interact with students such as delivering courses contents and assignments. Furthermore, all students in the university have accounts on a Student Information System which allow them to add/drop courses and follow up with their attendance status and grades. Regarding eexams, the percentages were relatively low also. Lebanese French University scored the highest because some departments are using an e-exam system officially for making quizzes and exams such as IT department while in other departments there are some initiatives by a few lecturers in using Google classroom application for making quizzes. Regarding employing e-learning in extracurricular activities the ratios were very low in all universities since most lecturers focus on co-curricular as the researcher believes. However, ratios of using E-Systems for calculating courses grades were high only in Tishk University due to lack of such systems in other universities. Regarding embedding e-learning in the classroom effectively, all ratios were very low and that's possibly due to lack of training teaching staff and necessary tools. 


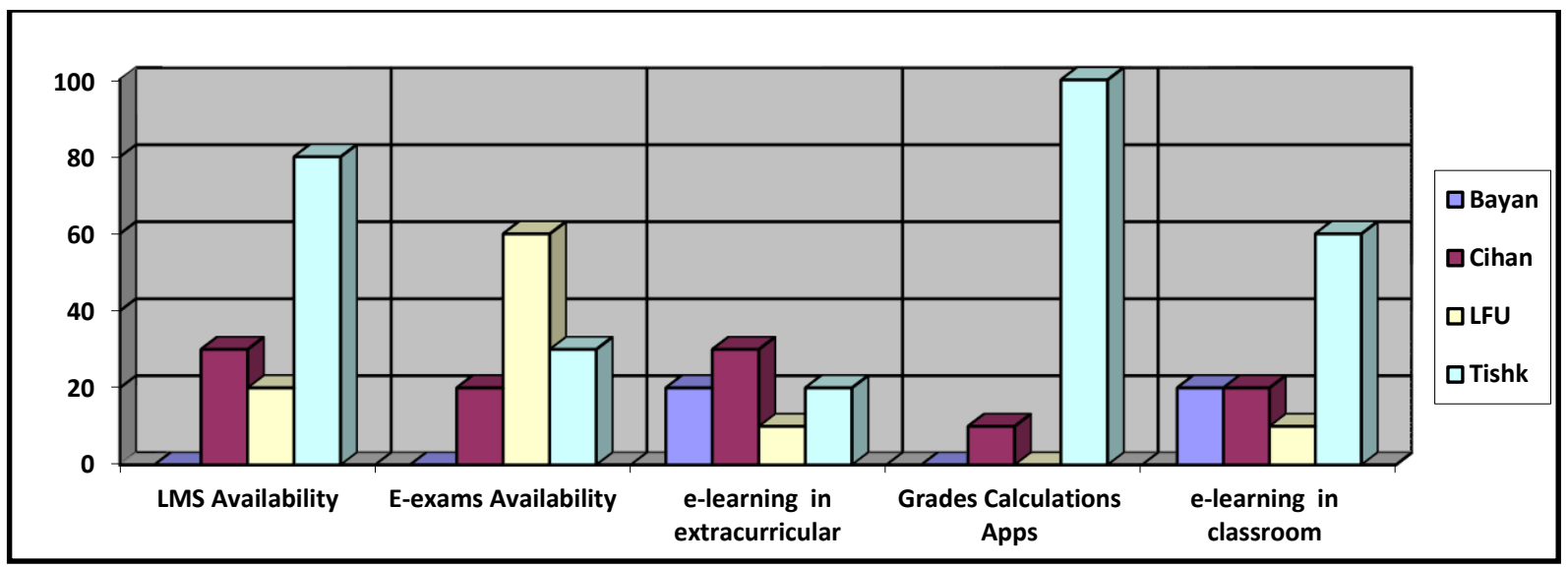

Figure 1: Analytical chart of the $1^{\text {st }}$ section of the questionnaire answers

Concerning the use of other educational technologies in universities, the results are displayed and Figure 2 below.

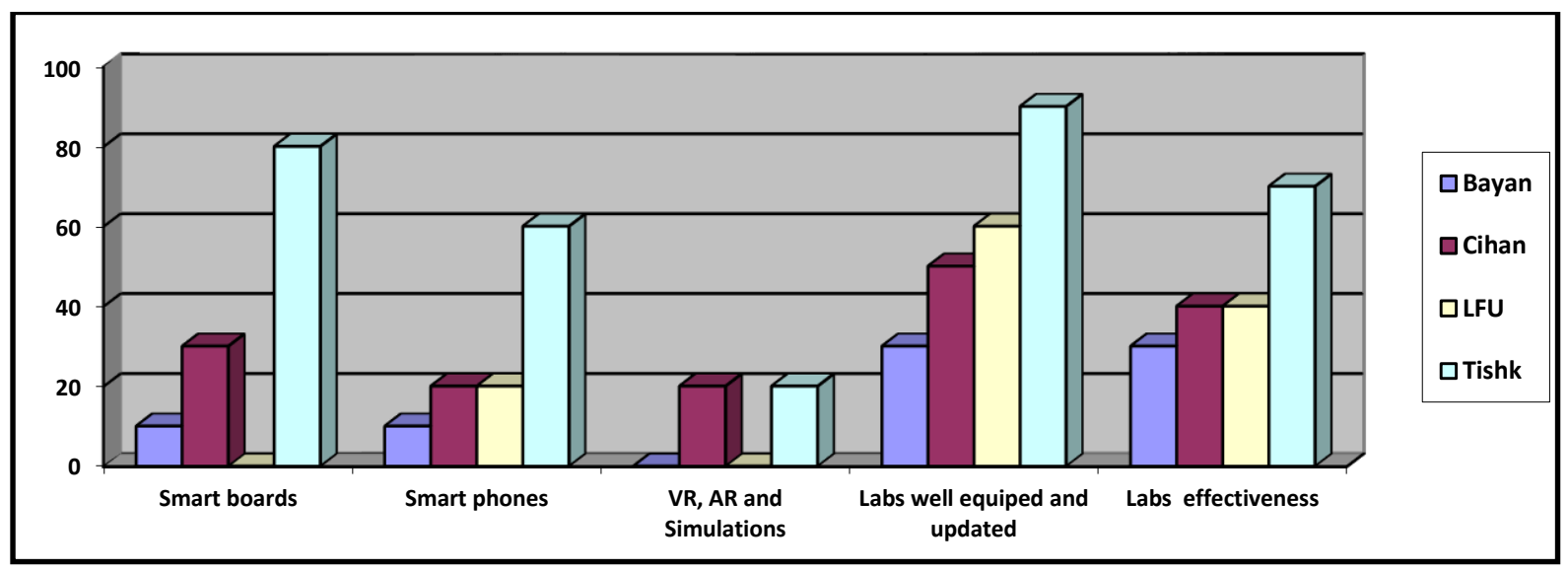

Figure 2: Analytical chart of the $2^{\text {nd }}$ section of the questionnaire answers

With respect to the second section, which contains questions on using other educational technologies rather than LMS and e-learning systems, the results revealed that most universities are lacking for smart boards except Tishk University which the best in this area. Regarding smartphones and tablets, there are very small ratios of students in most universities using their phones for learning excluding Tishk university where most students are using Edmodo and student system. Regarding modern technologies such as VR, $\mathrm{AR}$ and simulations, all ratios are extremely low which might reflect the absence of these technologies in universities. On the other hand, labs equipment seems to be the best in Tishk university then comes to other universities excluding Bayan University which might need to upgrade its labs. According to the academicians' answers, almost the same thing mentioned about lab equipment applied to the lab usefulness in delivering education.

From the obtained results, there is an obvious difference between Tishk and the other three universities in many aspects since Tishk is the best in terms of Labs quality, grades calculations apps, LMS and smart board implementation. However, Lebanese French is the best university in terms of adopting e-quizzes 
and exams in education. In addition, a huge difference in using smartphones in education is also observed between Tishk and other universities, since they use totally different educational systems where Tishk students are using Edmodo and students' online system to interact with courses and their related issues. Concerning the adopting of new technologies in education, it was observed that all universities still are not taking advantage out of these crucial tools which could add more interactivity if implemented wisely.

It can be observed from the study results, there is a need to increase the using of technology in education and there are obstacles at the same time. Tishk University has a unique experience within Erbil private universities, where students are using a special system for courses registration, grading, and attendance. On the other hand, Cihan University, Lebanese French University and Bayan University still they don't have LMSs yet.

The study results also show that some lecturers who are keen to technology and working in private universities in Erbil city without LMSs, they tend to use free services such as Google classroom, Moodle, or Edmodo to develop the learning process. However, the researcher believes that most of these trials are individual initiatives and depending on instructors' willingness to using technology in education.

One of the encouraging factors towards developing higher education in Kurdistan region of Iraq is the National University Ranking (NUR) of Kurdistan region-Iraq, which was founded by the Ministry of Higher Education (MHE-KRG) in 2015. NUR is assessing and ranking the Universities in different aspects. There are many criteria that support technological education in NUR, for example, university web presence, teaching quality assurance scoring and e-System (Nur-krg.net, 2018).

\section{Conclusion}

This study explores the application of educational technologies at private universities in Erbil city as an important part of the Kurdistan region of Iraq. The findings of this study were derived from questionnaires conducted on various academicians from four different private universities. The researcher selected the private universities because they play a significant role in education; such universities have supplied the educational systems and allow the adoption of education technologies easily. Therefore, lectures in higher education should pay attention and take advantage of the new trends of using technologies such as adaptive learning, virtual reality, augmented reality, simulations and cloud services. In addition, instructors in private universities should be provided with more advanced technologies in their classrooms such as smart boards. There is also a need for adopting LMS systems in private universities and offer training for lecturers on how to use these systems. Local researchers should look at top higher education countries such as South Korea and Japan, then compare technological education with Kurdistan region universities to find development areas. It is recommended that there should be professional IT teams at universities for supporting both lecturers and students in using modern educational technologies. Regarding e-Exam systems, there is no single system that fits with all educational courses; the key issue for making a successful e-Exam is the nature of course besides the willingness of the teacher to take advantages e-Exam. Finally, the awareness campaigns are very important to encourage instructors to implement new classroom technologies in private universities. 


\section{References}

Ahmad, M. E., Rashid, A. S. K., Abdullah, A. A., \& Abdulla, R. M. (2018). The role of information technology on teaching process in education: An analytical prospective study at university of Sulaimani. International Journal of Advanced Computer Science and Applications, 9(11), 512521.

Al-Hakeem, S., \& Abdulrahman, S. (2017). Developing a new e-exam platform to enhance the university academic examinations: The case of Lebanese French University. International Journal of Modern Education and Computer Science, 9(5), 9-16.

Al-Rahmi, W., Othman, M., \& Mi Yusuf, L. (2015). The effectiveness of using e-learning in Malaysian higher education: A case study universiti teknologi Malaysia. Mediterranean Journal of Social Sciences. doi: 10.5901/mjss.2015.v6n5s2p625

Anderson, S., Groulx, J., \& Maninger, R. (2011). Relationships among preservice teachers' technologyrelated abilities, beliefs, and intentions to use technology in their future classrooms. Journal of Educational Computing Research, 45(3), 321-338.

Bereday, G. (1967). Reflections on comparative methodology in education, 1964-1966. Comparative Education, 3(3), 169-287. doi: 10.1080/0305006670030304

Boyinbode, O., Agbonifo, O., \& Ogundare, A. (2017). Supporting Mobile Learning with WhatsApp based on Media Richness. Circulation in Computer Science, 2(3), 37-46.

Courts, B., \& Tucker, J. (2012). Using technology to create a dynamic classroom experience. Journal of College Teaching \& Learning (TLC), 9(2), 121.

Delgado, A., Wardlow, L., O’Malley, K., \& McKnight, K. (2015). Educational technology: A review of the integration, resources, and effectiveness of technology in K-12 classrooms. Journal of Information Technology Education: Research, 14, 397-416.

Dotong, C., L. De Castro, E., A. Dolot, J., Theresa, B., \& Prenda, M. (2016). Barriers for educational technology integration in contemporary classroom environment. Asia Pacific Journal of Education, Arts and Sciences, 3(2), 13-20.

Fadhil, A., \& Al-Ameen, Z. (2016). E-Learning at private universities in Kurdistan region: A comparative field study. International Journal of Modern Education and Computer Science, $8(9), 35-42$.

Kidd, J. R. (1975). Comparative adult education: The first decade. Comparative Studies in Adult Education: An Anthology, 5-24.

Ministry of Higher Education and Scientific Research. (2017). Higher Education in Kurdistan Region. Retrieved on July 20, 2017 from http://www.mhe-krg.org/node/3332

Mishra S. (2009). Educational technology: A definition with commentary - By Alan Januszewski \& Michae Molenda. British Journal of Educational Technology, 40(1), 187-187.

Nur-krg.net. (2018). Methodology - NUR-KRG. Retrieved on February 18, 2018 from http://www.nur-krg.net/methodology

Rambe, P., \& Bere, A. (2013). Using mobile instant messaging to leverage learner participation and transform pedagogy at a South African University of Technology. British Journal of Educational Technology, 44(4), 544-561.

Rehan A. S., \& Un, N. M. (2016). The significance of educational technology in teaching learning process. The International Journal of Indian Psychology, 4(1).

Phillips, D. (2006). Comparative education: Method. Research in Comparative and International Education, 1(4), 304-319. doi: 10.2304/rcie.2006.1.4.304

Sadik, M. (2018). Educational planning: Approaches, trends, and learnings a case study of the Kurdistan region of Iraq (KRI). SSRG International Journal of Economics and Management Studies, 5(6), $1-9$. 